\title{
THE EFFECT OF GUIDED INQUIRY LEARNING MODEL ON STUDENT'S LEARNING OUTCOMES IN TOPIC DYNAMIC ELECTRICITY IN CLASS X SEMESTER II SMA N 2 KISARAN A.Y.2014/2015
}

\author{
Lia Anggraini Siregar and Motlan \\ Physics Department, Faculty of Mathematics and Natural Science \\ lia.anggraini@gmail.com
}

\begin{abstract}
The research aimed to know the influence of guided inquiry learning model on student's learning outcomes in topic dynamic electricity in class X semester II SMA N 2 Kisaran A.Y 2014/2015. Beside that, the research also aimed to determine the differences between students learning outcomes by using guided inquiry learning model and conventional learning, and to know the student's activities as affective and psychomotor. The research used a quasi-experimental method. The population were all students of class $\mathrm{X}$ consist of 8 classes. The samples defined by cluster random sampling and conducted in class $X^{-1}$ as the experiment class and $X^{-}-2$ as the control class. The instruments were used learning outcomes test and the observation sheet.The result showed that the average value of posttest in experiment class is 64.25 higher than in control class is 53. The hypothesis result of posttest in experiment class and control class get $t_{\text {count }}(3.91)>t_{\text {table }}(1.67)$, so Ha can be accepted. The observation result showed student's activity in experiment class included in active category. Finally, it can be concluded that there is an effect of guided inquiry learning model on student's learning outcomes in topic dynamic electricity.
\end{abstract}

Keywords : guided inquiry learning model, student's learning outcomes, affective, psychomotor

\section{INTRODUCTION}

Nowadays, the change in science and technology is giving very much affect in the learning of physics at school. The most important influence is especially on the scope of learning materials and lesson delivery system. The comparison is not balanced between the scope physics wider with the least amount of available time, encourage teachers to teach quickly so that all the material can be delivered, regardless of whether learners have really understood or not. The fact that is the one factor causes of low achievement in learning physics.

According to Agustina and Tika (in Putra, 2013) expressed low student achievement is also evident from the results or reports several studies showing that science learning outcomes have not been focused on understanding and concept of real science, dominated by the lecture method of teaching. Generally a lecture on physics teaching in schools is still centered on the teacher (teacher centered), teachers only explain what he taught without asking whether or not students understand what is being learned. Students are only required to study the understanding and formulation without understanding physics lesson in the use of natural phenomena, and daily life as well as the times.

Based on the experience of researcher in Integrated Field Experience Program (PPLT) in SMA N 2 Kisaran, physics teachers generally conduct the learning by using calculations or to discuss the questions. 
It happened because of teacher is still using conventional learning, where in conventional learning teacher just explain what he want to teach and student just only listening to their teacher. The activity in the conventional class is very monotonous and not developed. Activity of student only notes what their teacher writes in the whiteboard and less doing experiment among teaching and learning process. It made a result that students feel bored, saturated, and cannot absorb the material presented by the teacher. So the achievement gained by the students was very low.

Learning physics can actually understand if students are given direct experience.Provision of direct experience is intended to further develop student's competence. In the study of physics students are directed to seek to know and do in order to help students to gain a deeper mastery. Therefore, learning must to be presented as attractive as possible so that students are interested to be involved directly in the learning process.

One goal of learning physics is mastery of the concept. Student involvement in the learning process gives good impact to be able to understand the concepts being studied physics. Mastery of concepts can help students define concepts (Arends, 2008). Thus, it is necessary to develop the level of mastery of concepts students in learning physics.

Guided inquiry model is one way in which to use inquiry-based learning in science education. Guided inquiry learning starts from the problems posed teachers can not be explained easily or can not be explained quickly. Then students make observations to the conclusion.However, the teacher controls the questions expressed, hypotheses are made and what the students observe (Sofiani, 2011). According to Burns (in Acre, 2010) it Involves learning activities that allow students to discover concepts and make sense of the natural world by themselves instead of relying on teachers and textbooks for interpretations. Thus, the process of using guided inquiry learning can help students understand the concepts of physics more deeply and help him think better. Guided inquiry learning model is part of the learning activities with contextual approach. Acquired knowledge and skills of students are expected not only of the result given the facts, but also of finding themselves. In the process, student is not only act as recipients, but their role is to find itself the core of the subject matter.

The research has been carried out by Ambarsari (2013), Suwondo (2013), and Putri (2014), the result of this research is suitable with their research result, where in their result gotten student's outcomes taught by guided inquiry learning model better than conventional learning. The disadvantages in the previous researcher, among others are guided inquiry model by applying the model requires a long time, so that the teachers had difficulty in the learning process. In the group discussions there were some students who are silent or less actively participate in group discussions. To overcome the above weakness, researcher will manage time in accordance with the plans that have been made in the design of the learning program or lesson plan.

\section{METHOD}

The research used a quasiexperimental method. This research was conducted in SMA N 2 Kisaran Class X Semester II Academic Year 2014/2015. The population were all students of class X consist of 8 classes. The samples defined by cluster random sampling and conducted in class $\mathrm{X}^{-1}$ as the experiment class (class treated by guided inquiry learning model) and X-2 as the control class (class treated by 
conventional learning), each class consist of 40 students.

The instrument of this research used learning outcomes tests consist of pre-test and post-test in multiple choice with 20 questions and 5 options that have been declared valid by expert before and the observation sheet to observed affective and psychomotor student's ability.

The study involved in two classes which are experimental class and control class, both these classes are given different treatments. Experimental class given guided inquiry learning model while the control class given conventional learning.

To determine student learning outcomes obtained with two treatments, the students were given the test twice: before treatment and after treatment. Test given before treatment $\left(\mathrm{T}_{1}\right)$ is called the pretest and test given after treatment $\left(\mathrm{T}_{2}\right)$ is called the posttest. The research design can be seen in the table 1 below:

Table 1. Research design

\begin{tabular}{|l|c|c|c|}
\hline \multicolumn{1}{|c|}{ Class } & $\begin{array}{c}\text { Pret } \\
\text { est }\end{array}$ & $\begin{array}{c}\text { Treat } \\
\text { ment }\end{array}$ & $\begin{array}{c}\text { Post } \\
\text { test }\end{array}$ \\
\hline Experiment & $\mathrm{T}_{1}$ & $\mathrm{X}$ & $\mathrm{T}_{2}$ \\
\hline Control & $\mathrm{T}_{1}$ & $\mathrm{Y}$ & $\mathrm{T}_{2}$ \\
\hline
\end{tabular}

Where:

$$
\begin{aligned}
\mathrm{T}_{1}= & \text { Pre-Test for experiment class } \\
& \text { and control class } \\
\mathrm{T}_{2}= & \text { Post-Test for experiment class } \\
& \text { and control class } \\
\mathrm{X}= & \begin{array}{l}
\text { Treatment with guided inquiry } \\
\text { learning }
\end{array} \\
\mathrm{Y}= & \text { Treatment with conventional } \\
& \text { learning }
\end{aligned}
$$

From the pretest result will do some prerequisite test, which is normality test for determine whether or not the normal distribution of data relating to data analysis. After normality test, next do homogeneity test that is to know if the data homogeneous or not. If the data have normal distribution and homogeneous, so for the next step do t test two tail that is to know first ability of student, $\mathrm{T}$ test is used to determine the similar ability of students in both groups of samples. If both groups of samples known have similar ability so both of samples will give different treatment. The experiment class given guided inquiry learning and the other class as a control class given conventional learning treatment. After giving treatment, both of class will give posttest. For calculating the post test data same with pretest calculation with normality test and homogeneity test. If the data have normal distribution and homogeneous, so for the next step do $t$ test one tail that is to know last ability of student that is used to know whether the student's learning outcomes by using guided inquiry learning in topic dynamic electricity accepted or not.

\section{RESULT AND DISCUSSION Research Result}

The research treatment gives in three times meeting. The research data is a student's learning outcomes with pretest, posttest, and observation data as affective and psychomotor aspects. Pretest gives before the learning process begins. Posttest gives after the learning process over.

From the result of research, the pretest of students in experiment class and control class get average pretest value in experiment class is 46.88 while the average pretest value in control class is 44.75 . After given a treatment in experiment class with guided inquiry learning model get an average value is 64.25 while in control class with conventional learning get an average value is 53 .

Hypothesis data calculated by using $t$ test one tail. In summary, it can be seen in the table 2 below: 
Table 2. Hypothesis test data in experiment class and control class

\begin{tabular}{|c|c|c|c|c|}
\hline Data & $\begin{array}{c}\text { Aver } \\
\text { age }\end{array}$ & $t_{\text {count }}$ & $t_{\text {table }}$ & $\begin{array}{r}\text { Conclusi } \\
\text { on }\end{array}$ \\
\hline $\begin{array}{c}\text { Experime } \\
\text { nt Class }\end{array}$ & $\begin{array}{c}64.2 \\
5 \\
\end{array}$ & \multirow{2}{*}{$\begin{array}{c}3.9 \\
1\end{array}$} & \multirow{2}{*}{$\begin{array}{c}1.6 \\
7\end{array}$} & \multirow{2}{*}{$\begin{array}{c}\text { Have } \\
\text { signific } \\
\text { ant } \\
\text { differen } \\
\text { t }\end{array}$} \\
\hline $\begin{array}{c}\text { Control } \\
\text { Class }\end{array}$ & $\begin{array}{c}53.0 \\
0\end{array}$ & & & \\
\hline
\end{tabular}

The observations have been done during teaching and learning process with three times meeting. From the affective result get learning affective by using guided inquiry learning model better than conventional learning. It can be seen in figure 1 below:

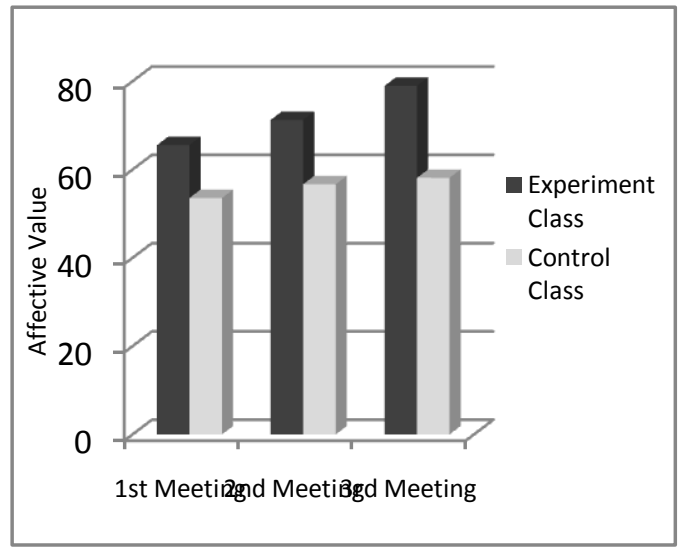

Figure 1. Affective Result

From the psychomotor observation results shows that the experiment class has ability in doing some experiment in the learning process. It can be seen in figure 2 below:

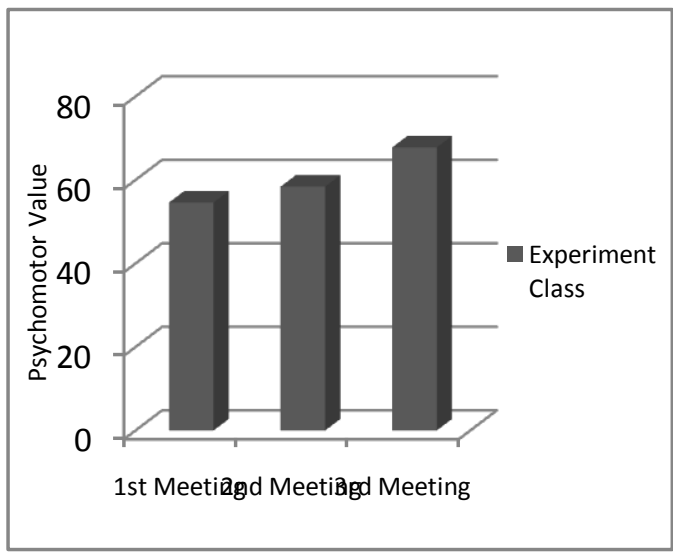

Figure 2. Psychomotor Result
From the result we know that in three times meeting the experiment class has been increased as activity and ability.

\section{Discussion}

This research was conducted in class $\mathrm{X}$ in two classes given different treatment, which is given control class with conventional learning and the experimental class given guided inquiry learning model in dynamic electricity in SMA N 2 Kisaran. Based on these results indicate that the average results in student learning in dynamic electricity in class $\mathrm{X}$ after being given a guided inquiry learning model (64.25) is higher than student learning outcomes by using conventional learning (53). This was confirmed by the differences of learning outcome in the experimental class with the control class that is equal to 11,25 or about $21.22 \%$ where $t_{\text {count }}>t_{\text {table }}$ that is $3.91>1.67$. This gives the sense that there is an effect exerted by guided inquiry learning model to student learning outcomes.

Guided inquiry learning model not only increased student learning outcomes, but also can enhance student learning activities as affective and psychomotor aspect. The result shows that the students in experiment class more active than in control class.

It is also described in some previous researched that is by Hussain, et al (2011) They said the students who taught by the guided, unguided and combination scientific inquiry methods of teaching were better in applying the concepts of physics to real life situations as compared to those students who were taught with traditional lecture method of teaching physics. Abdelraheem, et al (2006) they said this study showed that well designed an inquiry-based technology enhanced collaborative learning environment can enhance students learning experiences and found evidence that an inquiry-based technology enhanced collaborative learning can help students acquire and flexibly use complex knowledge. 
Suwondo (2013), he said the development and implementation of instructional design of the inquiry based active learning give a significant change in the lecture environment to put its main on the students, so that they can experience the improvement in their scientific attitudes and performance positively. Ambarsari (2013), she said research result showed that applied of guided inquiry learning model give significant effect to science process of student in VIII grade SMP Negeri 7 Surakarta. Pandey et al (2011), they said teaching of physical science through Inquiry Training Model is more effective than the teaching through the Conventional Method at the secondary level. The ITM model may be advocated as a better tool than the conventional method for teaching physical science. Bilgin (2009) as a result, when teaching materials which are prepared based on the guided inquiry instruction used in cooperative learning environment, students have developed their performance of acid and bases concepts and positive attitude toward guided instruction better than students are studies by themselves.

\section{CONCLUSION \& SUGGESTION Conclusion}

The conclusion of this study is based on findings from the data results of the research, carried out with due regard to grain systematic research objectives that have been formulated. The conclusions were obtained by using guided inquiry learning model in topic dynamic electricity in class $\mathrm{X}$ semester II SMA N 2 Kisaran A.Y 2014/2015 that is the average value of posttest in experiment class is 64.25 while in control class is 53 which means there is a difference because of the effect of guided inquiry learning model on student's learning outcomes. There is significant difference in learning outcomes where $t_{\text {count }}>t_{\text {table }}$ that is $3.91>1.67$. These results demonstrate the learning outcomes of students who are taught by guided inquiry learning modehs better than conventional learning. Learning activities of students in affective and psychomotor aspects during the learning process with guided inquiry learning model overall good and has active category.

\section{Suggestion}

Based on the research results and conclusions, then as a follow-up of this research the researcher suggested some suggestions that is for further researcher who wants to examine the learning model by using guided inquiry learning model because of the activities to be observed is so many, effectively takes one observer in each group, so it can not disturb the learning activity and make student more comfortable. For further researcher who wants to examine the learning model by using guided inquiry learning model may using a media in learning process to increased student outcomes. Learning media also can increase student's curiosity to find out knowledge what they learned by themselves.

\section{REFERENCES}

Abdelraheem, A., Asan, A., (2006), The effectiveness of inquiry-based technology enhanced collaborative learning environment,

International Journal of Technology in Teaching and Learning, 2(2). 65-87

Acre, A., (2010), Inquiry Learning in Physics, Thesis, University of Wisconsin Oshkosh, Oshkosh.

Ambarsari, W., Santosa, S., Maridi., (2013), Penerapan Pembelajaran Inkuiri TerbimbingTerhadap Keterampilan Proses Sains Dasar Pada Pelajaran Biologi Siswa Kelas VIII SMP Negeri 7 Surakarta, Journal of Biology Education, UNS.

Arends, R. I., (2008), Learning to Teach - Ninth Edition, McGraw-Hill Companies, New York.

Bilgin, I., (2009), The Effect of Guided Inquiry Instruction Incorporating. 
a Cooperative Learning Approach on University Students' Achievement of Acid and Bases Concepts and Attitude Toward Guided Inquiry Instruction, Scientific Research and Essay Vol.4 (10), pp. 1038-1046

Hussain, D. A., Azeem, M., Shakoor, A., (2011), Physics Teaching Methods: Scientific Inquiry $V_{S}$ Traditional lecture, International Journal of Humanity and Social Science, 1: 269-276

Pandey, A., Nanda, G. K., Ranjan V., (2011), Effectiveness of Inquiry Training Model over Conventional Teaching Method on Academic Achievement of Science Students in India, Journal of Innovative Research in Education 1(1). (pp. 720).

Putra, I. K., (2013), Pengaruh Model Pembelajaran Inkuiri Terbimbing Berbantuan Virtual Laboratory Terhadap Prestasi Belajar Fisika
Siswa Kelas VIII SMP Negeri 1 Singaraja Tahun Pelajaran 2013/2014, Skripsi, FMIPA.

Putri, W. R., (2014), The Effet of Guided Inquiry Learning Model on Student's Learning Outcomes in Topic Temperature and Heat in Class X Semester II SMA N 1 Berastagi Academic Year 2013/2014, Skripsi, FMIPA, Unimed, Medan.

Sofiani, E., (2011), Pengaruh Model Inkuiri Terbimbing (Guided Inquiry) Terhadap Hasil Belajar Fisika Siswa pada Konsep Listrik dinamis, Skripsi, FMIPA, UIN, Jakarta.

Suwondo., Wulandari, S., (2013), Inquiry-Based Active Learning: The Enhancement of Attitude and Understanding of the Concept of The Experimental Design in Biostatics Course, Asian Social Science. 